\title{
Arthur E. Adams, 1917-2007
}

Arthur Eugene Adams, emeritus professor of history and retired administrator at Ohio State University, died at his home in Columbus on 6 August 2007, barely four months before the death of his beloved wife and professional colleague, Jan S. Adams (see her obituary below), and just two days before their sixty-fifth wedding anniversary.

Art was born in Indianola, Iowa, on 11 April 1917. He received his BA from the University of Nebraska in 1942, the year of his marriage to Jan. He entered the United States Army in the same year and served overseas as an infantry officer, rising to the rank of major. Demobilized in 1946, he began graduate work in Russian history at Cornell University, where he studied with Marc Szeftel and received his $\mathrm{PhD}$ in 1951 with a dissertation titled "The Ideology and Influence of K. P. Pobedonostsev, 1881-1905."

After serving as instructor in Russian history at Cornell in 1950-51, Art spent his primary teaching career of almost twenty years (1951-1970) at Michigan State University (MSU), where in 1959 he received the university's award for outstanding teacher. Even during those decades, however, he took on many responsibilities outside the classroom, most notably as consultant to the Central Intelligence Agency (1952-1961), director of research for communist areas and policy board member of Radio Free Europe in Munich (1961-1963, on leave from MSU), chair of the Russian and East European Studies program at MSU (1963-1970), and director of MSU's Humanities Research Center (1967-1970).

When Art left Michigan State in 1970 to become professor of history and dean of the College of Humanities at Ohio State, he effectively left teaching behind for a succession of increasingly demanding administrative positions. After a seven-year stint as dean, at a time of considerable turmoil in American higher education, he served as associate provost (1977-1978), then vice-provost (1978-1982), and finally special assistant to the president for research and graduate studies (1982-1984). In the latter capacity, among other duties, he coordinated the planning for a large new research park at Ohio State. He retired from Ohio State in 1984.

Under Art's leadership as dean, the College of Humanities was an exciting place to teach and do research. Admired by many, feared by some, and respected by all, Art was the consummate dean. Some of the same qualities that earned him the nickname "the scoutmaster" at Radio Free Europe were in evidence at Ohio State in his insistence on high standards and his interest in the growth and development of faculty as well as students. His dean-like inclinations as well as his love of scholarship remained strong even at age 89 , when he phoned a friend to give him a suggestion for a new publication project. Art's support for our multidisciplinary Slavic studies programs was active and unwavering, as befits a person whose name stands first (courtesy of the alphabet) in the original published membership list (1961) of the American Association for the Advancement of Slavic Studies.

For the most part Art's scholarly writing in Russian history was concentrated, after his dissertation, in the 1960s and early 1970s. His major monographs were Bolsheviks in the Ukraine: The Second Campaign, 1918-1919 (1963), which received the Hoover Institute's Borden Award; Stalin and His Times (1972); and (coauthored with his wife, Jan) Men versus Systems: Agriculture in the USSR, Poland, and Czechoslovakia (1971). In addition, he was active as editor, coeditor, or compiler of several much-used collections of texts and documents in Russian history, including The Russian Revolution and Bolshevik Victory, Why and How? (1960), Imperial Russia after 1861: Peaceful Modernization or Revolution? (1965), and An Atlas of Russian and East European History (1967). After 1972, even as Art's administrative duties consumed more and more of his time, his scholarly publishing continued but was limited to articles, reviews, and updated editions of the earlier books.

Many, even among those who knew Art well, may be unaware that as a history professor at Michigan State he published a spy novel titled Double Agent (1959), under the pseudonym "Gene Stackelberg" (combining altered versions of his own middle name and his wife's maiden name). After retiring from Ohio State, he returned to this early avoca-

Slavic Review 67, no. 3 (Fall 2008) 
tion and published four more suspense thrillers, this time under his own name. Drawing on his experience in the military and the Central Intelligence Agency as well as his extensive travels on both sides of the Iron Curtain, he wrote fast-paced, tough-talking tales of espionage, crime, and international intrigue to which he brought the same authenticity and attention to detail that marked his scholarly publications. To gather material for one of the books, Special Agent (2000), which deals with the Colombian drug trade, he and Jan traveled to Medellin-not your typical tourist destination in the late 1990s, especially for an octogenarian. The other titles in this second writing career are Quimby (1988), Beware the Pale Horse (1999), and Moscow Nights (2000). In addition, Art worked throughout his retirement as Jan's research assistant.

Another of Art's distinctions, surely unique among American Slavic specialists, is that a university street is named for him. His contribution to the development of the research park at Ohio State in the 1980s was valued so highly by the Board of Trustees that they gave his name to the park's main thoroughfare. His Ohio State colleagues as well as his family are immensely pleased to have Arthur E. Adams Drive as a point of public homage on the campus, not far from Woody Hayes Drive.

\author{
James P. SCANLan \\ Ohio State University \\ January 2008
}

\title{
Jan S. Adams, 1920-2007
}

Jan S. Adams, retired international studies administrator and adjunct professor of political science at Ohio State University, died at her home in Columbus on 9 December 2007, four months and three days after the death of her professional colleague and beloved husband of sixty-five years, Arthur E. Adams.

Born Ouida Janet Steckelberg in Lincoln, Nebraska, on 10 March 1920, Jan graduated cum laude and Phi Beta Kappa from the University of Nebraska in 1942 with majors in English and music. She and Art married in the same year, shortly before he enlisted in the U.S. Army. After the war, as Art did his graduate study at Cornell University, Jan devoted herself to raising their two children, Russell and Catherine, helping Art as research assistant and typist, and studying Russian informally. After the family moved to Michigan State University in 1951, Jan began graduate study in international politics with an emphasis on Russia, working with Alfred G. Meyer and others. She earned an MA in 1966 and the $\mathrm{PhD}$ in 1971, with a dissertation directed by Ellen Mickiewicz on the role of the People's Control Committee in Soviet government.

Jan was fifty when she and Art moved to Ohio State in 1970 and she began her professional career as administrator and teacher. For the first year, she was a part-time instructor in political science, but upon receipt of the $\mathrm{PhD}$ she was appointed assistant professor and director of the newly formed Center for Undergraduate International Studies, in which capacity, among other duties, she administered the new international studies major. When this center was expanded beyond undergraduate studies and renamed the Center for International Studies in 1975, Jan was again named director, a position she held until a year before her retirement, along with the title of adjunct associate professor of political science. During that last year-1985-1986 - Jan's administrative responsibilities were expanded once more when she was appointed acting vice-provost for international affairs.

What the mere enumeration of these roles does not adequately convey is that each of them required a pioneering effort on Jan's part. At each stage, she was breaking new ground at Ohio State, administratively and educationally, and laying the foundation for the complex structure of instruction and research in international studies that exists at Ohio State today. Along the way, she also took time to serve as executive secretary of the American Association for the Advancement of Slavic Studies for two contentious years, $1978-1980$.

Jan's primary interest, of course, was always Slavic studies, and from the beginning she was a driving force in the development of the field at Ohio State, as I can testify from 